\title{
手指動作記述文間の類似性に基づく類似の 動作特徴を含む手話単語対の抽出方法
}

\author{
安達久博十
}

手話言語は，主に手指動作表現により単語の表出・受容を行う視覚言語としての側面 を持つ。そのため, 手話単語を構成する手指動作特徵の要素（例えば，手の形，手の 位置，手の動き）の一部を変更することで別の手話単語を構成できる特徵がある．特 に, 手指動作特徴の一つの要素だけが異なる単語対を手話単語の最小対と呼ぶ。また, 手指動作特徴の類似性が意味の類似性を反映している場合がある。このように，類似 の手指動作特徴を含む手話単語対は意味関係を内包する可能性があるなど, 手話単語 の分類を行うための重要な手がかりの一つとなると考える, すなわち, 類似の動作特 徵を含む手話単語対は言語学的に重要であるばかりでなく, 手話単語の検索処理や登 録・編集処理機能を実現する上でも重要な知識データと捉えることができる．本論文 では, 類似した手指動作特徴を含む手話単語対を与えられた手話単語の集合から抽出 する方法として，市販の手話辞典に記述されている手指動作記述文間の類似性に着目 し, この手指動作記述文間の類似性を手話単語間の手指動作特徵の類似性と捉え, 手 指動作記述文間の類似度計算に基づき最小対を抽出する方法を提案する。実験により, 提案手法の妥当性を示す結果が得られた。

キーワード：手話単語，最小対，類似度，最長共有部分列

\section{An Extraction Method of Similar Signs Based on Similarity between Manual Motion Descriptions}

\author{
HisAHIRO ADACHI ${ }^{\dagger}$
}

Sign language has an interesting characteristic that a change in part of the manual motion properties in hand-shape, location, movement often results in changing the meaning of signs. It is particularly called a minimal pair that the difference of properties between two signs is only one feature element. In building an electronic sign dictionary system, a couple of signs with similar manual motion properties play an important role in the retrieval, registration and synthesizing mechanism. This paper proposes a method for extracting a couple of signs with similar manual motion properties from a given set of signs. The method is based on the similarity between two signs, which is derived from the longest common subsequence(LCS) between manual motion descriptions(MMDs). It can be considered that a MMD represents information extracted from a series of motions of a sign. By computing the feature vectors of $n$ properties from MMDs and plotting them in the $n$-dimensional Euclidean space, an angle between two vectors can be considered as the similarity between two signs. However, when the feature vector can be considered as a string of MMD, the similarity can be obtained by string matching between the two MMDs. The results of evaluation experiments show the applicability of the proposed method. 
KeyWords: Sign, Minimal pair, Similarity relation, Longest common subsequence

\section{1 はじめに}

手話言語は，主に手指動作表現により単語を表出するため，手指動作特徴の類似性が意味の 類似性を反映している場合がある。例えば，図1に示した「午前」と「午後」という日本語ラべ ルに対応する二つの手話単語の手話表現を比較すると，手の動きが逆方向，すなわち，線対称 な関係にあることが分かる、ここで, 手話単語の手指動作特徴を手の形, 手の位置, 手の動き とした場合 (Stokoe, Casterline, and Croneberg 1976)，この単語対は，手の動きに関する手指 動作特徵だけが異なる手話の単語対である。また, 意味的には対義を構成し, 動作特徵の類似 性が意味の類似性を反映している単語対と捉えることができる。なお，手指動作特徵の一つだ けが異なる単語対を特に，手話単語の最小対と呼ぶ (Deuchar 1984). 明らかに，図 1に示した 単語対は，手の動きを対立観点とする手話単語の最小対を構成している.
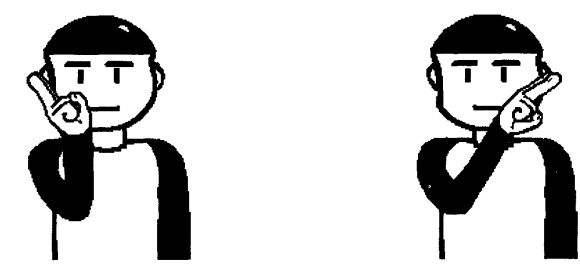

図 1 手の動きを対立観点とする手話単語の最小対 (午前, 午後)

このように，類似した動作特徴を含む手話の単語対の抽出と収集は，言語学分野における， 手話単語の構造と造語法を解明する手がかりとして，重要であるばかりでなく，手話言語を対 象とする計算機処理にも有益な知識データの一つとなる。例えば，計算機による手話単語の認 識処理においては，認識誤りを生ずる可能性が高い単語対の一つと捉えることができる．一般 に，人間の認識過程においても非常に類似している（差異が小さい）二つのオブジェクトを認 識する際に，何の情報トリガも無ければ，同一のオブジェクトとして認識してしまう傾向があ る.しかし,「このペアは似ているけど違うよ」というような情報トリガが与えられると, 認識 をより精密に行おうと（差異を検出）する傾向が見られる。一方，手話表現の生成処理におい ては, ある手話単語の手指動作特徵パラメータの一部を変更することで, 別の手話表現を生成 できることを意味する。また，日本語と手話単語との対訳電子化辞書システムを核とする学習 支援システムの検索処理においては, 類似の動作特徵を含む他の手話単語と関連付けて検索で きるなど，学習効果の向上に貢献できるものと考える.

$†$ 宇都宮大学 工学部 情報工学科, Department of Information Science, Utsunomiya University 
本論文では, 類似した手指動作特徵を含む手話言語の単語対 (以後, 本論文では, 類似手話 単語対と略記する.) を与えられた単語集合から抽出する方法を提案し, その有効性を検証する ために行った実験結果について述べる、本手法の特徵は, 市販の手話辞典に記述されている手 指動作記述文を手指動作の特徵構造を自然言語文に写像した手指動作パターンの特徵系列と捉 え，手指動作記述文間の類似度計算に基づき，類似手話単語対を抽出する点にある。

なお, 関連する研究として, 音声言語1を対象とした同様なアプローチとして, 市販の国語 辞典や英語辞書に記述されている語義文（あるいは定義文）の情報を利用した単語間の意味関 係や階層関係を抽出する研究 (中村, 酒井 1987; 冨浦, 日高, 吉田 1991; 鶴丸, 井上, 日高, 吉田 1992; 丹羽, 新田 1993, など) が報告されている.

以下, 2 章では, 本研究の対象言語データである手指動作記述文の特徴と, その特徵から導 出される特徵べクトル表現について，3 章では, 手指動作記述文間の類似性に基づく手話単語 間の類似度の計算方法について，4章では，本提案手法の有効性を検証するために行った実験 結果を示し， 5 章で考察を行う.

\section{2 手指動作記述文の特徵とベクトル表現}

本研究で使用する手話辞典 (丸山 1984) は, 図 1に示したように, 手話単語見出しに対して, その手指動作手続きをイラストで表現する部分と, 自然言語文で表現する手指動作記述文の部 分で構成されている，前章で説明したように，図1の手話イラストの比較から, 手話単語対（午 前, 午後) は, 手の形, 手の位置に関する手指動作特徵が共通で, 手の動き（右に倒すか左に 倒すか 2 ）に関する手指動作特徵だけが異なる手話単語の最小対を構成していることが分かる. ここで，手話辞典に記述されている手指動作記述文を以下に示す.

・午前 右手の人差指と中指を立てて額の中央にあて、右に倒す

- 午後右手の人差指と中指を立てて額の中央にあて、そのまま左に倒す

明らかに，手指動作記述文の比較からも同様に，手の動きを示す部分だけが異なることが容 易に理解できる。このように, 手指動作記述文は, 手話単語の動画像の特徵構造を, 構造を持 つ 1 次元の記号系列 (日本語文) に写像した特徵系列と捉えることができる.すなわち, 手話 単語の手指動作表現を生成するための手続きを記述したプログラム（手続き）文と捉えること ができる。また，手指動作記述文は一般の自然言語文と比べて，使用される語彙（単語集合） は，手や顔の部位を表す名詞や手指の動きを表現する動詞が制限され，動作の手続き文として の特徵から, 文中での単語の配列（文形式）に制約がある。これらの特徵から, 手指動作記述 文は言語の使用環境が，一般の自然言語文に比べて，語彙的にも構文的にも強い制約を受けた

1 本論文では, 手話言語と対比させる意味で書記言語としての特徴を持つ日本語や英語などを総称して, 音声言語と呼ぶ ことにする.

2 辞書に記述されている手指記述文では, 手話を行う動作主体から見た場合の方向で記述されている. 
文集合と捉えることができる。

\section{1 手指動作記述文のベクトル表現}

日本語文の形態素解析規則は，原則として，正規文法で記述できることが知られている(丸 山, 荻野 1994). さらに, 前節で議論した特徵から, 手指動作記述文は構文的にも語彙的にも非 常に限定された文集合である。一般に，ある範囲の限定された文集合を認識する有限オートマト ンは比較的簡単に構成することができる (長尾 1983). 議論を明確にするため, 以下に示す例で は，与えられた三つの手指動作記述文の文集合を認識する有限オートマトンの状態遷移図を示 し，そこから導出される正規表現の文字列に基づく $n$ 次元の特徵べクトル表現について述べる. 例 手話単語 $A, B, C$ に対する手指動作記述文を， $A$ =右手の親指を上げる， $B$ =左手の小 指を下げる, $C=$ 両手の小指を曲げるとする．図 2 は，この三つの手指動作記述文を受理 する有限状態遷移図を示す 3 .

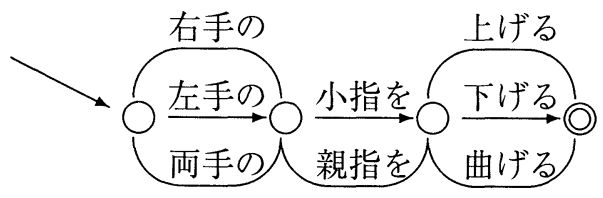

図 2 有限状態遷移図

次に，図 2 に示した有限状態遷移図から導出される文節単位の正規表現と文字連接に基づく 正規表現を以下に示す.

\section{- 文節単位の正規表現}

(右手 |左手 |両手) の+ (親指 $\mid$ 小指)を+(上げる|下げる|曲げる $)$

\section{- 文字連接に基づく正規表現}

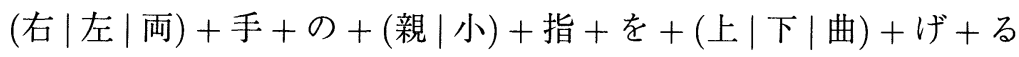

ここで，文字の連接関係を保持した形で，正規表現の各文字を手話単語（すなわち，手指動 作記述文）の特徵観点と定義し，この特徴観点の有無を 2 值 $\{0,1\}$ で表現すると，表 1 に示した ように, 手話単語 $A, B, C$ は, 上記の手続きにより, 手指動作記述文から導出される 14 次元の 特徵ビット・ベクトルで表現することができる.このように，与えられた手指動作記述文の有 限集合を受理する有限オートマトンを構成し, 正規表現による文字系列の各文字を特徴観点と する $n$ 次元の特徽ビット・ベクトルで手話単語を表現することができる. 
表 1 手指動作記述文の特徵ビット・ベクトル

\begin{tabular}{l|llllllllllllll}
\hline & 右 & 左 & 両 & 手 & の & 親 & 小 & 指 & を & 上 & 曲 & げ & る \\
\hline \hline $\mathrm{A}$ & 1 & 0 & 0 & 1 & 1 & 1 & 0 & 1 & 1 & 1 & 0 & 0 & 1 & 1 \\
$\mathrm{~B}$ & 0 & 1 & 0 & 1 & 1 & 0 & 1 & 1 & 1 & 0 & 1 & 0 & 1 & 1 \\
$\mathrm{C}$ & 0 & 0 & 1 & 1 & 1 & 0 & 1 & 1 & 1 & 0 & 0 & 1 & 1 & 1 \\
\hline
\end{tabular}

\section{3 手話単語間の類似度の考え方}

パターン認識においては，一般に，二つのパターン間の関係を計算するために，パターン空 間上での距離あるいは類似度を定義する必要がある (飯島 1989; 田中 1990，など)．例えば，(丸 山 渡辺 1989) は, 単語の意味関係を計算する方法として, 各単語を $n$ 次元のユークリッド意味 空間上の点と見なし, 点の座標を計算する代わりに各単語に多くの特徵観点を独立に収集し, 大数の法則に基づき $n$ 次元の特徵ベクトルを与え, 二つの単語間の意味の類似度を対応する特 徵ベクトル間のなす角として定義している.

本研究では, 手話単語を手指動作特徴の $n$ 次元の特徵パターン空間上の点とみなし, $n$ 次元 の特徵ベクトルのなす角を用いて，手話単語間の類似度を近似する。手話単語とそれに対応す る手指動作記述文は, 原則として 1 対 1 対応である。すなわち, 手話単語間の類似度問題は対 応する手指動作記述文間の類似度問題と捉えることができる。また，この手指動作記述文は， 前章で示したように, $n$ 次元の特徴ビットベクトルで表現できる.

\section{1 手指動作記述文間の類似度の計算方法}

任意に与えられた二つの手話単語 $A, B$ に対する手指動作記述文の文字系列から導出された, $n$ 次元の特徵べクトルを $\boldsymbol{A}=\left(a_{1}, a_{2}, \cdots, a_{n}\right), \boldsymbol{B}=\left(b_{1}, b_{2}, \cdots, b_{n}\right)$ とし, 二つの手指動作記述 文間の類似度を $S(\boldsymbol{A}, \boldsymbol{B})$ と表記するとき，類似度を次式で定義する。

$$
S(\boldsymbol{A}, \boldsymbol{B})=\cos ^{2} \theta=\frac{(\boldsymbol{A}, \boldsymbol{B})^{2}}{\|\boldsymbol{A}\|^{2}\|\boldsymbol{B}\|^{2}} \quad(0 \leq S(\boldsymbol{A}, \boldsymbol{B}) \leq 1)
$$

ここで, $(\boldsymbol{A}, \boldsymbol{B})$ は二つのべクトルの内積を表わし, $\|\boldsymbol{A}\|$ は,ベクトル $\boldsymbol{A}$ のノルムを表わし 次式で計算される.

$$
\begin{gathered}
(\boldsymbol{A}, \boldsymbol{B})=\sum_{k=1}^{n} a_{k} b_{k} \\
\|\boldsymbol{A}\|^{2}=(\sqrt{(\boldsymbol{A}, \boldsymbol{A})})^{2}=\left(\sqrt{\sum_{k=1}^{n} a_{k}^{2}}\right)^{2}=\sum_{k=1}^{n} a_{k}^{2}
\end{gathered}
$$

ここで, 計算対象となる特徵べクトルは，表 1 に示したように，要素成分の值が 2 值 $\{0,1\}$ 
で表現されるビットベクトルであるため, ベクトルのノルムの自乗は, 特徵ベクトルの要素成 分の值が 1 である要素の総数で計算できる.すなわち, 特徵べクトルに対応する手指動作記述 文の長さ 4 と等しくなる. 同様に, ベクトルの内積の自乗は, 二つの特徵ベクトルの各要素成分 の值が共に 1 である要素の総数で計算できる，これは，特徵べクトルに対応する手指動作記述 文間の最長共有部分列の長さと等しくなることを次節で述べる.

\section{2 最長共有部分列の長さの計算}

一般に，与えられた記号列の部分列とは，与えられた記号列から０個以上の記号を削除する ことにより得られる任意の記号列のことである. また，二つの文字列の最長共有部分列 (longest common subsequence) とは, 記号の出現順序（連接関係）を保存した形で, 双方に共通の部分 列のうち，最長の部分列のことである (Thomas, Charles, and Ronald 1990). 例えば, 二つの 記号列を, $X=a b c b d a b, Y=b d c a b a$ とすると, $X$ と $Y$ の最長共有部分列の一つは $b c b a$ であ り, その長さは 4 となる。一般に, 最長共有部分列は一つとは限らず複数存在する可能性があ る. 実際, $X$ と $Y$ の最長共有部分列は, 他に $b d a b$ と $b c a b$ がある.しかし, その長さは一意に 決定される，以下では，最長共有部分列の長さを計算する方法について述べる.

与えられた一つの系列 $X=x_{1} x_{2} \cdots x_{l}$ に対して, $i$ 番目 $(i=0,1, \cdots, l)$ までの部分列を $X_{i}=x_{1} x_{2} \cdots x_{i}$ と表記する．例えば， $X=a b c d e$ なら $X_{3}=a b c$ であり， $X_{0}$ は空列を意味す る.二つの系列を, $A=a_{1} a_{2} \cdots a_{m}$ と $B=b_{1} b_{2} \cdots b_{n}$ とする. また，二つの系列 $A$ と $B$ の最 長共有部分列の長さを $L C S(A, B)$ で表記すると，動的計画法を利用し，次式で計算される.

$$
\begin{gathered}
\operatorname{LCS}(A, B)=\operatorname{LCS}\left(A_{m}, B_{n}\right) \\
\operatorname{LCS}\left(A_{i}, B_{j}\right)= \begin{cases}\operatorname{LCS}\left(A_{i-1}, B_{j-1}\right)+1 & \text { if } a_{i}=b_{j}, \\
\max \left\{\operatorname{LCS}\left(A_{i}, B_{j-1}\right), \operatorname{LCS}\left(A_{i-1}, B_{j}\right)\right\} & \text { if } a_{i} \neq b_{j}\end{cases}
\end{gathered}
$$

ここで, $L C S\left(A_{i}, B_{j}\right)$ は部分列 $A_{i}$ と $B_{j}$ の最長共有部分列の長さを表わす。また， $1 \leq i \leq m, 1 \leq j \leq n$ であり, $\operatorname{LCS}\left(A_{i}, B_{0}\right)=\operatorname{LCS}\left(A_{0}, B_{j}\right)=0$ とする.なお, (Sato 1992) は, 複数存在する最長共有部分列を絞り込むため, この最長共有部分列の長さを求める 計算式に，文字連接の制約を考慮した関数を新たに導入し，類似例文の最適照合計算に利用し ている.

\section{3 文字列照合に基づく類似度の計算}

これまでの議論をまとめると, 手話単語間の類似度は, 対応する手指動作記述文間の類似度とみ なし, 二つの手話単語 $A, B$ に対する手指動作記述文の文字列を $A=a_{1} a_{2} \cdots a_{m}, B=b_{1} b_{2} \cdots b_{n}$ 4 手指動作記述文の長さとは，文を構成する文字数を意味する. 
とすると, (1) で定義した特徵べクトルに基づく手指動作記述文間の類似度 $S(\boldsymbol{A}, \boldsymbol{B})$ は、次式 で表現できる.

$$
S(\boldsymbol{A}, \boldsymbol{B})=\frac{L C S(A, B)^{2}}{m n}
$$

これにより, 有限オートマトンを求め, $n$ 次元の特徵ベクトルによるベクトル計算をする代 わりに，与えられた二つの手指動作記述文間の文字列照合により類似度が計算できることが導 ける。

\section{4 実験と考察}

\section{1 実験方法と結果}

実験には，手話辞典 (丸山 1984) に記述されている手指動作記述文の中から，二つの文字列 (「両手」, 「掌」) を両方含み, かつ複合語 5 を構成していない手話単語とその手指動作記述文 （142 文）を選定し，計算機に人手で入力したものを用いた ${ }^{6}$.なお，上記の選定条件に適合す るが，一つの手指動作記述文中に括弧書きで説明あるいは、別の手話表現が併記されている 17 文 (手話単語) は実験対象外とした。

実験方法は，手指動作記述文間の類似度を式 (5) に基づいて求め, 類似度が 0.6 以上の手話 単語対を抽出した。なお, 本論文で定義した類似度の計算式 $(5)$ は反射律 $(S(A, A)=1)$ と対 称律 $(S(A, B)=S(B, A))$ を満たすため, 例えば, $\mathrm{S}($ 休む, 閉める) と $\mathrm{S}($ 閉める, 休む) は, 片 方のみを計算した，評価方法としては，抽出された手話単語対を正解/不正解というような二義 的に判定することは適切でないと考え, 共通の手指動作特徵は何か, また異なる手指動作特徵 は何かを明らかにし, 手話単語の電子化辞書システムを構築する上で有用な情報が得られたか 否かで評価を行う.

実験の結果, 表 2 に示すように類似度が 0.6 以上の手話単語対として, 36 組の単語対が抽出 された。ここで, 表中の単語見出しの添字は, 同一の単語見出しに別の手話表現すなわち, 異な る手指動作記述文が手話辞典 (丸山 1984) に登録されていることを意味する.

次に, 抽出された各単語対の手指動作特徵の類似性を評価するため, 対応する二つの手指動 作記述文間の共有部分列と差異部分列を分析し, 手指動作特徵の共通属性と差異属性は何かを 明らかにする。

分析の結果，表 $3 に$ 示す 14 組の単語対は，同一の手話表現であることが分かった．なお，同 一の手話表現でありながら，類似度の值にばらつきが生じた原因については 5 章で議論する。

また，表 4 に示す 7 組の単語対は，掌の向きを対立観点とする手話単語の最小対である.同

5 例えば, 手話単語見出し【青森】は【青い】と【森】で複合語を構成し，それぞれの手指動作記述文が記述されている。 6 手指動作記述文中の句読点は, 挿入位置のゆらぎが文字列照合に影響を与えるため, 入力の段階で削除した. 
表 2 類似度 0.6 以上で抽出された手話単語対

\begin{tabular}{|c|c|c|c|c|c|}
\hline 類似度 & 手話単語 (1) & 手話単語 (2) & 類似度 & 手話単語 (1) & 手話単語 $(2)$ \\
\hline 1.00 & 働く & 仕事 & 0.64 & 陳列 & 豊か \\
\hline 1.00 & 鮮やか & 濃い & 0.64 & 忙しい A & 状態 \\
\hline 0.96 & 嬉しい & 楽しい & 0.63 & 終る A & 廃れる \\
\hline 0.93 & 明るい & 晴れ & 0.61 & 守る A & 気を付ける \\
\hline 0.87 & バランス B & 比ベる & 0.61 & いよいよ & 対応 \\
\hline 0.83 & 動摇 & 迷う & 0.60 & 贈る & 届ける \\
\hline 0.74 & 休む & 閉める & 0.60 & 勉強 & 比べる \\
\hline 0.74 & すべて & だいたい & 0.60 & 届く & 届ける \\
\hline 0.72 & 楽しい & 喜ぶ & 0.60 & 慌てる & 育てる \\
\hline 0.70 & 会舘 & センター & 0.60 & 比べる & 状態 \\
\hline 0.69 & 今 & 重い & 0.60 & 忙しいA & 比べる \\
\hline 0.69 & 終る A & 〜でした A & 0.60 & 林 & バランス B \\
\hline 0.68 & 一途 & 専念 & 0.60 & 与える & 発行 \\
\hline 0.67 & 林 & 比べる & 0.60 & 陳列 & 森 \\
\hline 0.67 & 嬉しい & 喜ぶ & 0.60 & 間 A & 贈る \\
\hline 0.67 & 遠慮 & 届く & 0.60 & 頂く & 届く \\
\hline 0.66 & 重い & 暇 & 0.60 & 慌てる & 豊か \\
\hline 0.65 & 戸 & 閉める & 0.60 & 多いA & 陳列 \\
\hline
\end{tabular}

表 3 同一の手話表現である手話単語対

\begin{tabular}{c|l|l||l|l|l}
\hline 類似度 & 手話単語 $(1)$ & 手話単語 $(2)$ & 類似度 & 手話単語 $(1)$ & 手話単語 $(2)$ \\
\hline \hline 1.00 & 働く & 任事 & 0.70 & 全舘 & センター \\
1.00 & 鮮やか & 濃い & 0.69 & 終るA & てでした A \\
0.96 & 嬉しい & 楽しい & 0.68 & 一途 & 専念 \\
0.93 & 明るい & 晴れ & 0.67 & 嬉しい & 喜ぶ \\
0.91 & バランス B & 比べる & 0.65 & 戸 & 閉める \\
0.83 & 動摇 & 迷う & 0.63 & 終るA & 廃れる \\
0.72 & 楽しい & 喜ぶ & 0.61 & 守るA & 気を付ける \\
\hline
\end{tabular}

様に，表 5 に示す 6 組の単語対は，手の動きを対立観点とする最小対である．なお，単語対（間

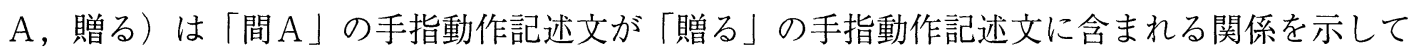
いる。すなわち,「間 A」の手話表現が「贈る」の手話表現の初期状態と捉えることができる.

表 4 掌の向きを対立観点とする手話単語対

\begin{tabular}{|c|c|c|c|}
\hline 手話単語 (1) & 手話単語 $(2)$ & 手話単語 (1) の特徴 & 手話単語 (2)の特徴 \\
\hline 休む & 閉める & 下に向ける & 前方に向 \\
\hline 林 & 比べる & 左右に向かい合わせる & 上に \\
\hline 遠慮 & & 左右に向かい合わせる & 上下に向かい合わせる \\
\hline 贈る & 届ける & 左右に向かい合わせる & 上下に向かい合わせる \\
\hline 慌てる & 育てる & (上に向ける) & 左右に向かい合わせる \\
\hline 林 & $\begin{array}{l}\text { バランス B } \\
\text { 届く }\end{array}$ & 左右に向かい合わせる & $\begin{array}{l}\text { 上に向ける } \\
\text { 上下に向かい合わせる }\end{array}$ \\
\hline & & 上に向ける & 上下に问かい合わせる \\
\hline
\end{tabular}

表 6 に示す 2 組の単語対は，手の位置を対立観点とする最小対である.さらに，表 7 に示し 
表 5 手の動きを対立観点とする手話単語対

\begin{tabular}{|c|c|c|c|}
\hline 手話単語 (1) & 手話単語 (2) & 手話単語 (1) の特徵 & 手話単語 (2) の特徵 \\
\hline $\begin{array}{l}\text { すべて } \\
\text { 重い } \\
\text { いよいよ } \\
\text { 届く } \\
\text { 与える } \\
\text { 間 } \mathrm{A}\end{array}$ & $\begin{array}{l}\text { だいたい } \\
\text { 暇 } \\
\text { 対応 } \\
\text { 届ける } \\
\text { 発行 } \\
\text { 贈る }\end{array}$ & $\begin{array}{l}\text { 而手を接触させる } \\
\text { 動作の移動量が多い } \\
\text { 片手を近付ける } \\
\text { 手前に動かす } \\
\text { 前方に弧を描く }\end{array}$ & $\begin{array}{l}\text { 両手を接触させない } \\
\text { 動作の移動量が少ない } \\
\text { 両手を近付ける } \\
\text { 前方に動かす } \\
\text { 左右に広げる } \\
\text { 関係 }\end{array}$ \\
\hline
\end{tabular}

た単語対は，指先の向きを対立観点とする最小対である。ここで，今回の実験に使用した手指 動作記述文では，指先の向きに関する情報の記述は明示されておらず，手指動作記述文間の比 較だけではこの関係は抽出できない.

表 6 手の位置を対立観点とする手話単語対

\begin{tabular}{l|l||l|l}
\hline 手話単語 $(1)$ & 手話単語 $(2)$ & 手話単語 $(1)$ の特徵 & 手話単語 $(2)$ の特徵 \\
\hline \hline 陳列 & 豊か & 腹の前 & 胸の前 \\
多いA & 陳列 & 胸の前 & 腹の前 \\
\hline
\end{tabular}

表 7 指先の向きを対立観点とする手話単語対

\begin{tabular}{l|l||l|l}
\hline 手話単語 $(1)$ & 手話単語 $(2)$ & 手話単語 $(1)$ の特徵 & 手話単語 $(2)$ の特徵 \\
\hline \hline 忙しいA & 比べる & 中央に向ける & 前方に向ける \\
\hline
\end{tabular}

このように，今回の実験に用いた手話辞典 (丸山 1984)では，イラストと手指動作記述文が 相互に情報を補完している。すなわち，指先の向きに関する情報はイラスト情報で提示されて いるため，本実験の類似度の計算には直接，反映されていないことが明らかとなった．また，実 験対象の手指動作記述文を抽出する際に指定した「両手」と「掌」を両方とも含む手話単語は， 結果として, 手の形に関しては「五指を広げた形」の手指動作特徵を共通の属性とする単語群 の一つであり，手の形を対立観点とする単語対は抽出されないことが分かった。なお，指先の 向きに関しては，例えば,「掌を上に」の場合と「掌を前方に」の場合とでは，指先の向きはそ れぞれ，前方と上方を指しているという違いはあるが，掌の向きと連動して変化することに着 目すると，指先の向きに関する動作特徴は掌の向きに関する動作特徵に吸収されているとみな して分析を行った。

残りの 6 組の単語対については，表 8 に示すように，基本となる動作を交互（点対称）に行 うか同時 (線対称) に行うか, 掌の向き, 手の位置, 指先の向きなど複数の特徵観点の違いが見 られる。ここで, 二つの単語対 (勉強, 比べる) と（慌てる, 豊か) は, 手指動作記述文間の文 
字列の比較を基準とする本提案手法の問題点を示している。これについては，5章で議論する.

表 8 複数の特徵観点で異なる手話単語対

\begin{tabular}{|c|c|c|c|c|}
\hline 手話単語 & 手の位置 & 掌の向き & 手の動き & 指先の向き \\
\hline 今 & - & 下下に向ける & 二度程下におろす & - \\
\hline 重い & - & 上に向ける & 下におろす & - \\
\hline 勉強 & - & 顔に向ける & 同時に上下させる & - \\
\hline 比べる & - & 上に向ける & 交互に上下させる & - \\
\hline 陳列 & - & 上に向ける & 同時に上下させながら左右に広げる & - \\
\hline 森 & - & 手前に向ける & 交互に上下させながら左右に広げる & - \\
\hline 忙しいA & 胸の前 & 上に向ける & - & 中央に向ける \\
\hline 状態 & 顔の前 & 前に向ける & - & 上に向ける \\
\hline 比べる & 胸の前 & 上に向ける & - & - \\
\hline 状態 & 顔の前 & 前に向ける & - & - \\
\hline 慌てる & 腹の前 & - & 交互に上下させながら上にあげる & 中央に向ける \\
\hline 豊か & 胸の前 & - & 同時に上下させながら左右に広げる & 前方に向ける \\
\hline
\end{tabular}

次に, これらの分析結果を基に, 抽出された手話単語対が手話単語の電子化辞書の構築（計 算機処理）に有用な情報が抽出できたか否かについて，利用方法の例を示しながら評価を行う.

- 同一の手話表現である単語対

市販の手話辞書を基に, 機械可読形式に変換する場合, 同一の手話表現を持つ単語見出 しを抽出することは, 対応する手話画像データとのリンクを効率的に関係付ける上で重 要であり, 手話表現から対応する日本語の単語見出しを検索する機能を実現する上でも 重要な知識源の一つと捉えることができる。また，手話を日本語に変換する手話通訳シ ステムにおける訳語選択において，有効利用できると考える。例えば,「明るい」と「晴 れ」,「迷う」と「動摇」などは文脈に応じて適切な日本語単語見出しを選択する必要が ある。このように, 従来の手話電子化辞書の多くが, ある一つの日本語単語見出しに対 して, 複数の手話表現が対応する訳し分け7に重点をおき構成されていたものを，ある手 話表現に対して, 複数の日本語単語見出しが対応する点を考慮して, 再構成する必要性 を示唆するものと考える。

- 最小対

手話単語の最小対は, 手話単語の造語法の解明に重要な知識データの一つとなる。一方, 掌の向き, 手の位置, 手の動き, 指先の向きを対立観点としているため, 手話表現をア二 メーションで表現する際に, 両者の差異となる手指動作特徵項目のみを変更することで, 生成できる可能性がある，例えば，複数の画像フレームを連続的に表示して，動画ア二 メーションを生成する場合に、表示する配列順序を逆転させることで「届く」と「届け る」の両方を同一の画像フレーム集合で生成できる。また，学習支援システムとしての 電子化辞書の場合には, ある手話単語を検索した場合に, 手指動作特徵の一部だけが異 7 例えば,「あがる」に対して, 雨があがる, 成績があがる, 階段をあがるなど. 
なる他の手話単語を提示し, 両者間の差異を認識させることで, 学習効果が向上できる と考える.

このように, 今回の実験で抽出された単語対を分析した結果, 抽出された 36 組の単語対の 中で 30 組は, 非常に類似した手指動作特徵を含む単語対である. また, 手話単語の計算機処理 に有用な単語対と捉えることができ，本提案手法の有効性を示す結果が得られたと考える。し かし, 分析の結果, 幾つかの問題点も明らかになった.これらの問題点と今後の課題について, 次章で詳細に議論する。

\section{5 考察}

まず最初に，同一の手話表現でありながら，類似度の值にばらつきが生じた原因について， 以下に手指動作記述文間の差異を明示しながら分析を行う。例として, 類似度が 0.6 の (守る A，気を付ける）の手話単語対の手指動作記述文間の差分を以下に示す。ここで，文中の記号 “ 【”と“】”でくくられた部分が相違部分文字列を示す.

守る A 掌を手前に向けた両手を【胸の前に上下にして】おき手前 に引き寄せ【ると同時に拳をさっと】重ねて胸にあてる

気を付ける 掌を手前に向けた両手を【上下にして胸の前に】おき手前 に引き寄せ【ながらさっと拳を】重ねて胸にあてる

明らかに，二つの手指動作記述文は同一の手指動作を表現している。しかしながら，文字列 【胸の前に】と【上下にして】が双方の手指動作記述文間で逆転している。このような関係は， 文字の出現順序を考慮しながら照合を行う, 最長共有部分文字列検索を基本とする類似度の計 算方法では，類似度の值が低下する要因として働くここの場合には、文字数の多い【上下にし て】が共有部分列として計算される, 同様に,【さっと】は副詞であり, その挿入位置は日本語 文中では比較的自由度が大きく,【さっと拳を】も【拳をさっと】も日本語文としては正しい. 次 に，類似度が低下する他の要因について分析する．表 $3 に$ 示した中で，(明るい，晴れ），(動摇, 迷う）の手話単語対は片方の手指動作記述文が両者の最長共有部分文字列に相当し，それぞれ， 【同時】，【摇らすように】が付加されている違いがある，従って，類似度計算では，この差分の 文字数により類似度の值が変動している。このように，同一の動作表現を別の表現方法を用い て記述されている等の要因が複合化され, 結果として, 同一の手話表現であるにもかかわらず、 類似度が低下する要因として働いている．上記の問題を解決する方法の一つとして，与えられ た手指動作記述文を認識の観点ではなく, 生成の観点から有限オートマトンを再構成するなど の正規化手法を検討することが考えられる．この正規化手法については今後の課題である.

次に, 表 8 中の単語対 (勉強, 比べる) と（慌てる, 豊か) は, 文字列の照合法に基づく本 手法の限界を示している. 例えば, (勉強, 比べる) における, 手の動きに関する記述文間の差 
異は, 上下の動作を同時に行うか交互に行うかの違いがある. また，掌の向きの差異は，顔に 向けるか上に向けるかの違いと判断できる。しかし,「顔に向ける」の意味するところは, 本を 読むしぐさを表現しており，手話表現では斜めに両手を構えて，斜めに上下する動作を表現し ている。また，(慌てる，豊か）は，複合動作を表現しているため，「慌てる」が上方に両手を上 げてゆく動作に対して,「豊か」が左右に広げてゆく動作である。しかし，これらの動作表現を 示す文形式の共有部分が動作の差異を表現する部分より極端に大きいため, 本論文の類似度の 計算では，高い類似度となる。

このように，手指動作記述文間の比較だけから手話単語対の詳細な分析は困難であるが，本 論文で提案した手法を用い，与えられた単語集合の膨大な組合せの中から，分析対象となる類 似の手話単語対の候補を適切な閾値を設定することで容易に抽出し, 収集することができると 考える.

\section{6 むすび}

本論文では，与えられた手話単語集合から類似の動作特徵を含む手話単語対を抽出する方法 として，市販の手話辞典に記述されている手指動作記述文間の類似性に着目した手法を提案し た。本手法の特徵は, 手話単語間の動作特徵の類似関係を対応する手指動作記述文間の類似関 係と捉え，手話単語間の類似度を手指動作記述文間の類似度で計算する点にある。類似度が 0.6 以上の手話単語対を抽出する実験の結果, 手話単語の認識や生成, 検索処理に有用な手話単語 の最小対や類似の動作特徴を含む手話単語対を抽出できることを確認した. 今後の課題として, 与えられた手指動作記述文を正規化する手法の検討と手指動作特徵の類似性に基づく手話単語 の体系化を試みる予定である。

\section{謝辞}

本研究を進めるにあたり有益なご示唆, ご討論を頂いた宇都宮大学鎌田一雄教授, 熊谷毅助 教授に感謝する。また，デー夕整理，実験等にご協力頂いた研究室の学生諸氏に感謝する。な お, 本研究の一部は文部省科研費, 厚生省科研費, 実吉奨学会, 電気通信普及財団, 放送文化 基金，トヨ夕自動車，栢森情報科学振興財団，大川情報通信基金の援助によった.

\section{参考文献}

Deuchar, M. (1984). British Sign Language. Routledge \& Kegan Paul.

飯島泰蔵 (1989). パターン認識理論. 森北出版.

丸山宏 渡辺日出雄 (1989). “マイクロフィーチャーに基づく語間の関連度の計算とその適合化.”

NLC89-1, 信学技報. 
丸山宏 荻野紫穂 (1994). “正規文法に基づく日本語形態素解析.” 情報処理学会論文誌, 35 (7), 1293-1299.

丸山浩路 (1984). イラスト手話辞典. KK ダイナミックセラーズ.

長尾真 (1983). 言語工学. 昭晃堂.

中村順一 酒井圭一 (1987). “英々辞典を用いた名詞の意味関係の分析.” NLC86-23, 信学技報. 丹羽芳樹 新田義彦 (1993). “日常辞書の語義文参照ネットワーク上での単語間距離計算に基づ く単語の数值列表現方法.” NLC93-40, 信学技報.

Sato, S. (1992). "CTM:An Example-Based Translation Aid System." In Proceedings of COLING92, pp. 1259-1263.

Stokoe, W. C., Casterline, D. C., and Croneberg, C. G. (1976). A dictionary of American Sign Language on linguistic principles (new ed.). Linstok Press (originally published in 1965).

田中栄一 (1990). “構造を持つものの距離と類似度.”情報処理, 31 (9), 1270-1279.

Thomas, H. C., Charles, E. L., and Ronald, L. R. (1990). Introduction to Algorithms. MIT Press.

鶴丸弘昭, 井上淳, 日高達, 吉田将 (1992). “語義文からの階層関係の自動抽出.” NLC92-2, 信 学技報.

冨浦洋一, 日高達, 吉田将 (1991). “語義文からの動詞間の上位一下位関係の抽出.”情報処理学 会論文誌, $32(1), 42-49$.

\section{略歴}

安達 久博: 1981 年宇都宮大学工学部情報工学科卒業. 1983 年同大学院工学研 究科修士課程修了. 同年，東京芝浦電気（現．東芝）入社. 同社総合研究所 情報システム研究所研究員を経て，1992 年宇都宮大学工学部助手．現在に 至る。この間，科学技術庁の機械翻訳プロジェクトに従事のため京都大学 $(1983.10-1984.10)$ に滞在. 通産省主導による自然言語処理用大規模電子 化辞書プロジェクトに従事のため日本電子化辞書研究所 $(1985.5$ - 1989.5) に出向（第五研究室室長代理）。現在，聴覚障害者の情報獲得を支援する手 話通訳システムに関する研究に従事. 言語処理学会, 情報処理学会, 電子情 報通信学会, 人工知能学会, 日本認知科学会, 計量国語学会, 各会員. 